\title{
Optimasi pembangkit daya hibrid dengan energi terbarukan (studi kasus di Desa Koak NTT)
}

\author{
Eli Kumolosari ${ }^{1}$, Yulia Venti Yoanita ${ }^{2}$, Sinung Tirtha Pinindriya ${ }^{3}$ \\ ${ }^{1}$ Departemen Teknik Mesin Sekolah Tinggi Teknologi Adisutjipto Yogyakarta \\ ${ }^{2}$ Fakultas Keguruan dan Ilmu Pendidikan Universitas PGRI Yogyakarta \\ ${ }^{3}$ Pusat Teknologi Penerbangan Lembaga Penerbangan dan Antariksa Nasional (LAPAN) \\ Email Korespondensi: *elikumolosari@ stta.ac.id
}

\begin{abstract}
Abstrak. Rasio elektrifikasi Indonesia masih belum 100\%. Dua Propinsi bahkan masih di bawah $70 \%$, salah satunya Nusa Tenggara Timur, yaitu sebesar 59,85\%. Salah satu desa di NTT, yaitu Desa Koak, sebanyak 457 dari 471 KK belum menikmati listrik. Di sisi lain, desa tersebut memiliki potensi energi surya dan angin yang cukup baik. Penelitian dilakukan untuk mendapatkan sistem hibrid yang paling optimal untuk diterapkan di desa tersebut. Penelitian dilakukan dengan simulasi menggunakan software HOMER Pro. Hasil simulasi menunjukkan bahwa sistem hibrid yang paling optimal adalah kombinasi PV dan turbin angin, dengan tambahan komponen baterai dan converter. Energi surya menyumbang produksi daya sebesar 92,3\% dari total daya yang dihasilkan, dan energi angin menyumbang 7,7\%. Biaya awal yang dibutuhkan untuk membangun sistem ini adalah \$14328 dan NPC sebesar \$24586. Sistem ini ramah lingkungan karena emisinya 0 .
\end{abstract}

Kata kunci: optimasi, pembangkit daya, HOMER Pro, energi terbarukan, energi surya, energi angin, NTT

\section{Pendahuluan}

Indonesia merupakan negara berkembang yang terdiri dari 34 Propinsi, mulai dari Aceh di ujung barat hingga Papua di ujung timur. Sebagai negara berkembang, beberapa permasalahan masih belum terselesaikan, salah satunya adalah masalah kelistrikan. Rasio elektrifikasi di Indonesia masih sebesar 95,35\%, yang artinya 4,65\% rakyat Indonesia masih belum bisa menikmati listrik [1]. Dua Propinsi bahkan rasio elektrifikasinya masih di bawah $70 \%$, yaitu Nusa Tenggara Timur dan Papua dengan rasio elektrifikasi $59,85 \%$ dan $61,42 \%$ secara berturut-turut.

Permasalahan yang seringkali menjadi alasan belum meratanya penyebaran listrik di Indonesia adalah lokasi. Beberapa desa terletak di area yang terpencil, sehingga cukup sulit untuk menjangkaunya, apalagi dengan peralatan yang harus dibawa. Selain itu, belum adanya listrik juga terkait dengan ijin yang belum didapat dari suatu cagar alam yang terlewati Proyek kelistrikan tersebut. Padahal, alam Indonesia sangat kaya, apalagi di daerah terpencil, di mana sumber daya alam masih sangat banyak. Hal tersebut tentu saja terkait dengan sumber energi terbarukan yang bisa dimanfaatkan untuk pemenuhan kebutuhan listrik setempat. Sumber energi terbarukan sendiri cukup banyak ragamnya, mulai dari surya, angin, air, biomasa, dan sebagainya. 


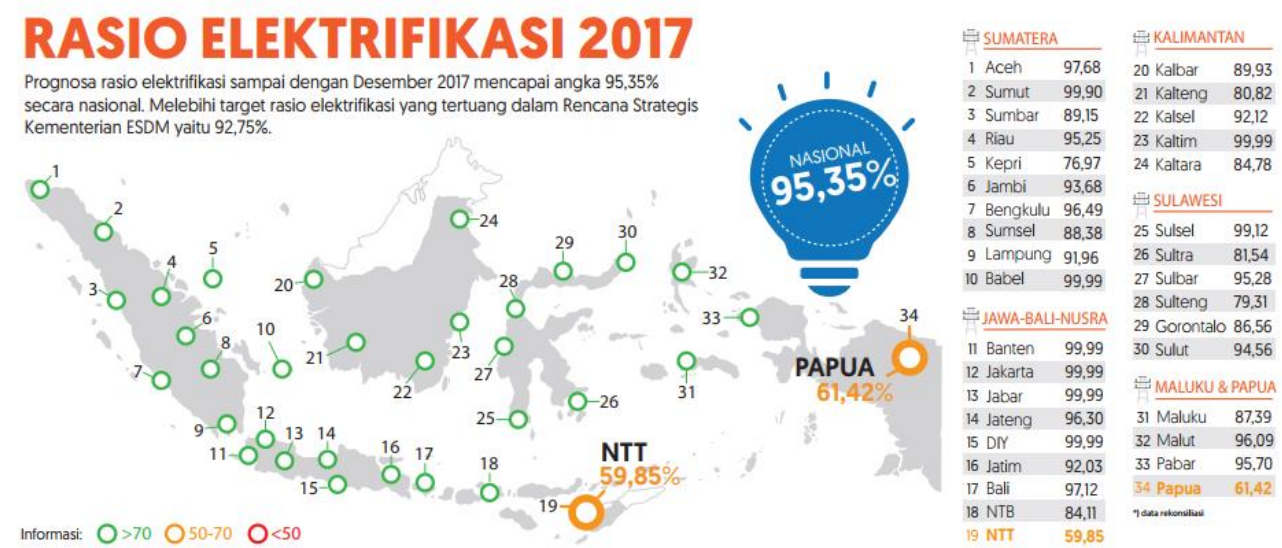

Gambar 1. Rasio elektrifikasi di Indonesia [1]

Propinsi Nusa Tenggara Timur (NTT) merupakan Propinsi yang beribukota di Kupang dan terletak di sebelah tenggara Indonesia. Propinsi ini terdiri dari beberapa pulau, yaitu Pulau Flores, Pulau Sumba, Pulau Timor, Pulau Alor, Pulau Lembata, Pulau Rote, Pulau Sabu, Pulau Adonara, Pulau Solor, Pulau Komodo dan Pulau Palue. NTT memiliki 22 kota dan kabupaten, 309 kecamatan, dan 3353 desa. Dari ribuan desa di NTT, beberapa desa masih belum bisa menikmati listrik. Salah satu di antaranya adalah Desa Koak, Kecamatan Satar Mese, Kabupaten Manggarai. Desa tersebut terletak di Pulau Flores dan letaknya berada di tepi pantai, seperti terlihat pada Gambar 2. Dari ratusan KK yang ada di Desa Koak, baru 14 KK yang bisa menikmati listrik (bukan PLN), dan sisanya sebanyak 457 KK masih belum bisa [2]. Di sisi lain, Desa Koak memiliki sumber daya energi yang bisa dimanfaatkan, yaitu surya dan angin.

Berdasarkan latar belakang di atas, dalam penelitian ini akan disajikan rancangan pembangkit daya yang paling optimal untuk diterapkan di Desa Koak, dengan energi hibrid. Asumsi pada rancangan ini adalah listrik untuk $40 \mathrm{KK}$. Penelitian dilakukan dengan simulasi menggunakan software HOMER Pro (Evaluation Version). HOMER Pro merupakan software yang berfungsi untuk simulasi sistem pembangkit daya hibrid yang tujuannya untuk mendapatkan sistem yang paling optimal. Hasil dari penelitian ini diharapkan bisa menjadi gambaran penyediaan listrik paling optimal di Desa Koak, sehingga masyarakat Desa Koak bisa menikmati listrik dan meningkatkan taraf hidupnya.

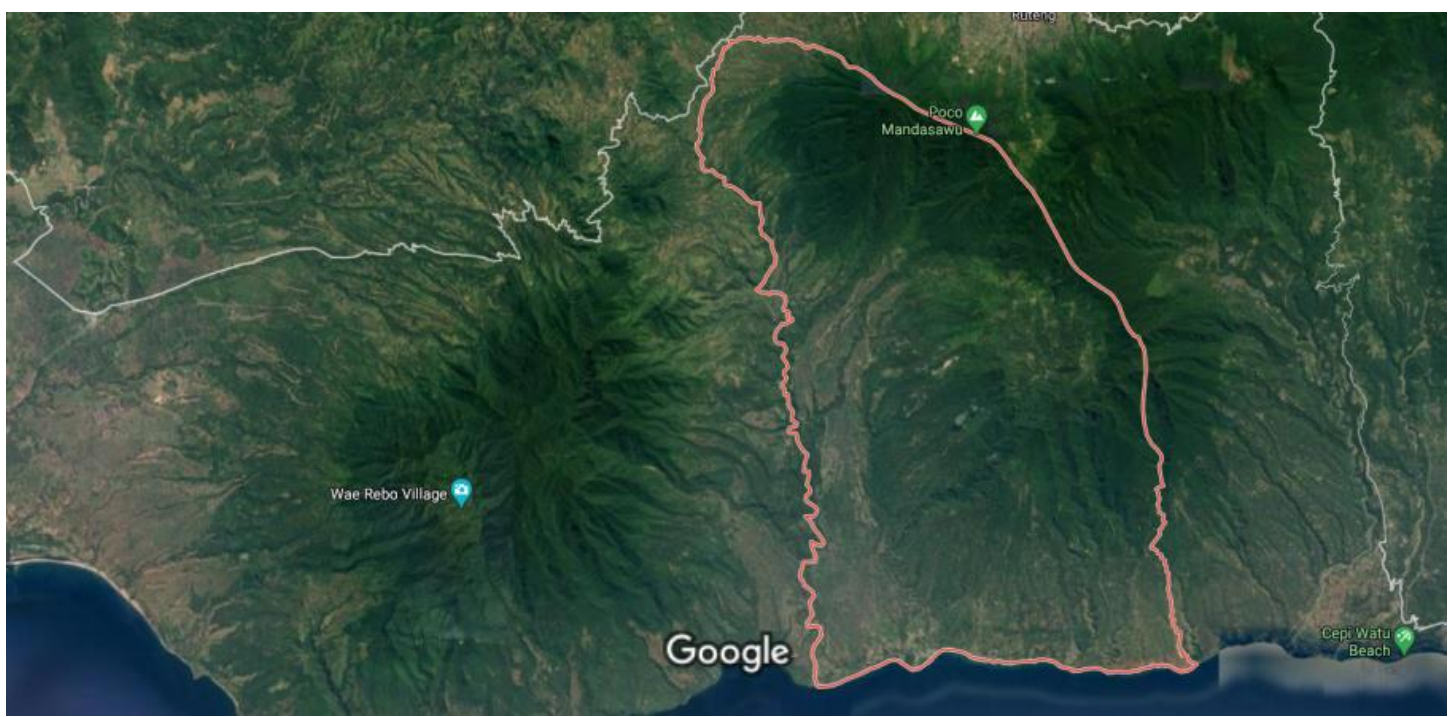

Gambar 2. Peta Kecamatan Satar Mese, Kabupaten Manggarai [3] 
Desa Koak bependuduk 1908 jiwa dengan 471 kepala keluarga. Tabel 1 menunjukkan Profil Desa Koak.

Tabel 1. Profil Desa Koak, Kecamatan Satar Mese, Kabupaten Manggarai [2]

\begin{tabular}{ll}
\hline Luas & $25,6 \mathrm{~km}^{2}$ \\
\hline Jumlah penduduk & 1908 \\
Jumlah KK & 471 \\
Jumlah KK pengguna listrik & 14 (Bukan PLN) \\
Jumlah KK bukan pengguna listrik & 457 \\
BB untuk memasak & Kayu Bakar \\
Sungai & Tidak Ada \\
Pantai & Ada \\
Jumlah sekolah & 4 \\
Jumlah tempat ibadah & 1 \\
Sarana transportasi antar desa (darat) & Ada, dengan trayek tetap \\
Kondisi jalan darat & Aspal/beton, dapat dilalui kendaraan bermotor roda 4 atau \\
Titik koordinat & lebih \\
Geografi & $8,7990^{\circ}$ LS dan 120,4990 BT \\
\hline
\end{tabular}

Desa Koak memiliki potensi energi terbarukan berupa surya dan angin yang cukup baik. Gambar 3 dan 4 menunjukkan potensi energi surya dan angin di Desa Koak secara berturut-turut. Dari Gambar 3 terlihat bahwa rata-rata radiasi surya di Desa Koak adalah $5,63 \mathrm{kWh} / \mathrm{m}^{2} /$ hari. Nilai tersebut cukup baik untuk dimanfaatkan sebagai pembangkit listrik.

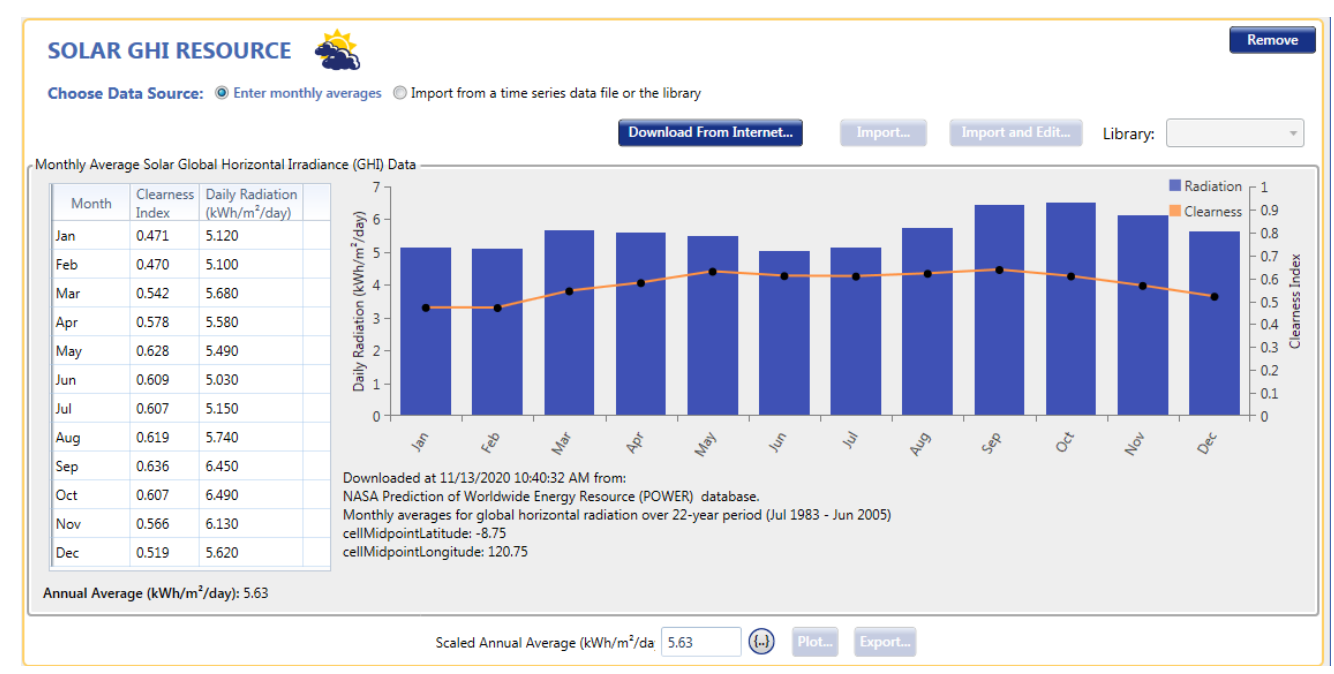

Gambar 3. Potensi energi surya di Desa Koak

Dari Gambar 4 terlihat bahwa rata-rata kecepatan angin di Desa Koak adalah 3,02 m/s. Nilai tersebut sedikit berada di atas nilai minimal untuk dimanfaatkan sebagai pembangkit listrik, sehingga akan dimasukkan ke simulasi sebagai pertimbangan. 


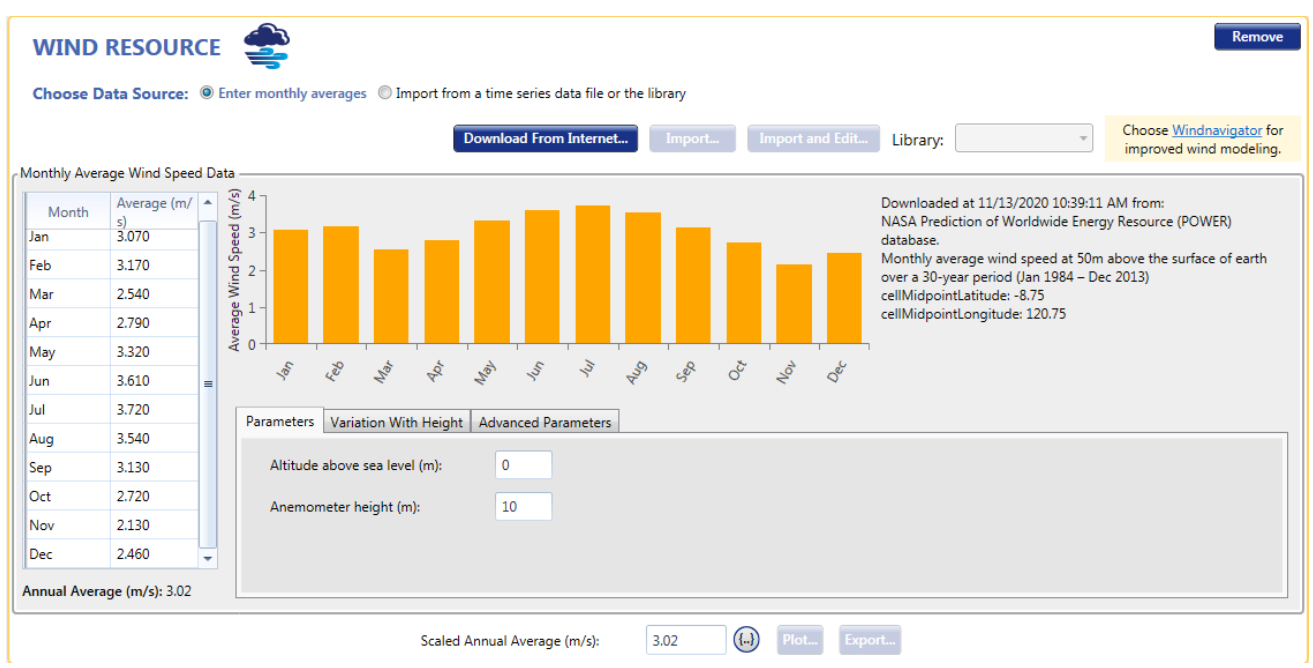

Gambar 4. Potensi energi angin di Desa Koak

\section{Metode Penelitian}

Pelaksanaan penelitian dimulai dengan studi literatur, dilanjutkan perumusan masalah, kemudian pengumpulan data sekunder yang diambil dari berbagai sumber, simulasi dengan HOMER Pro, analisis hasil, penarikan kesimpulan, dan selesai. Gambar 5 adalah diagram alir penelitian.

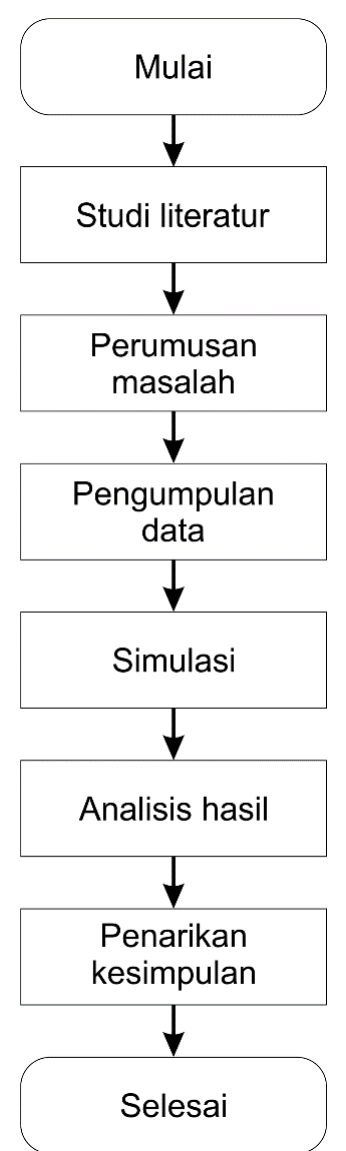

Gambar 5. Diagram alir penelitian 
Simulasi dilakukan dengan menggunakan software HOMER Pro (Evaluation Version). Diagram alir simulasi terlihat pada Gambar 6. Langkah pertama dalam simulasi ini adalah memasukkan lokasi yang menjadi objek penelitian, yaitu Desa Koak, Kecamatan Satar Mese, Kabupaten Manggarai, NTT. Lokasi tersebut akan merujuk pada sumber daya alam yang tersedia di tempat tersebut. Dalam penelitian ini, sumber daya yang dimanfaatkan adalah surya dan angin. Potensi tersebut digunakan sebagai pertimbangan awal apakah memungkinkan untuk dimanfaatkan sebagai pembangkit daya atau tidak. Data potensi surya dan angin diperoleh dari website NASA yang menjadi rujukan software HOMER Pro ini.

Langkah selanjutnya adalah memasukkan beban per jam untuk $40 \mathrm{KK}$, seperti terlihat pada Gambar 7 . Data beban tersebut diperoleh dari asumsi penggunaan daya per jam, di mana pada pukul $18.00-20.00$ merupakan puncak beban. Hal ini disebabkan seluruh anggota keluarga sudah berada di rumah dan melakukan aktivitas di rumah. Pada pukul 06.00, beban juga berada di puncak karena anggota keluarga mulai beraktivitas kembali, seperti menyetrika dan menyalakan pompa air. Sementara beban terendah terjadi pada jam istirahat malam, di mana diasumsikan bahwa semua alat elektronik dimatikan, kecuali sedikit lampu saja.

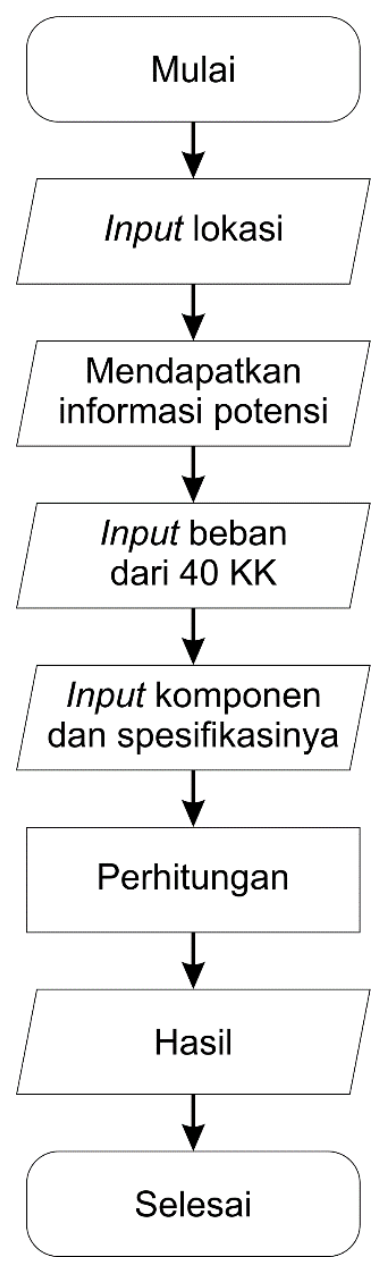

Gambar 6. Diagram alir simulasi 


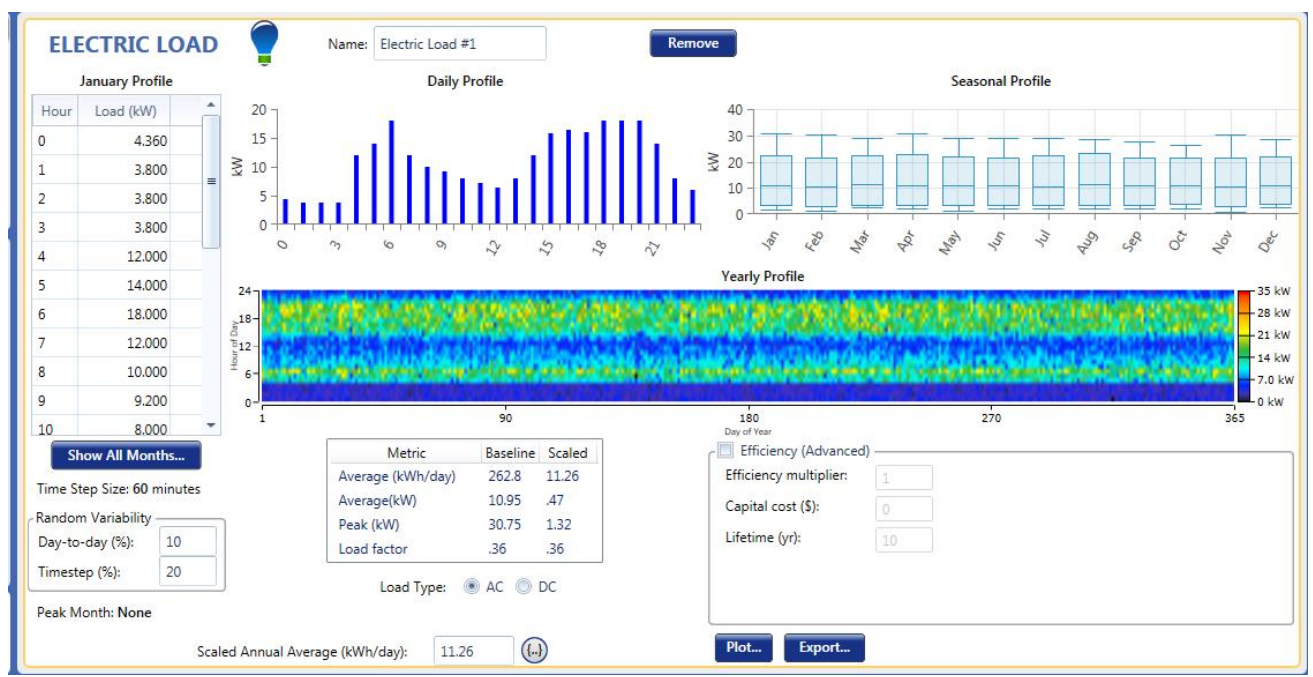

Gambar 7. Beban daya $40 \mathrm{KK}$

Setelah data beban dimasukkan, langkah selanjutnya adalah memasukkan beberapa komponen, yaitu seperti terlihat pada Gambar 8. Komponen tersebut adalah PV, turbin angin, genset, converter, dan baterai. Genset berbahan bakar solar dimasukkan sebagai pertimbangan sistem hibrid yang paling optimal.

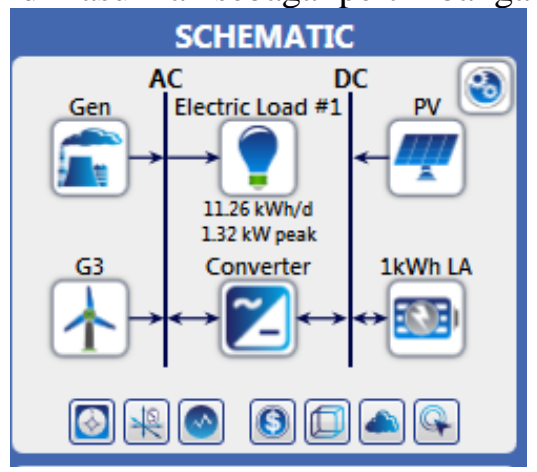

Gambar 8. Konfigurasi komponen dalam simulasi

Proses input komponen membutuhkan beberapa data, yaitu harga di pasaran (dalam USD), lifetime, kapasitas, serta harga bahan bakar (untuk genset). Gambar 9 menunjukkan salah satu contoh input data komponen, dalam hal ini adalah PV. Langkah terakhir adalah perhitungan hingga didapatkan hasil. 


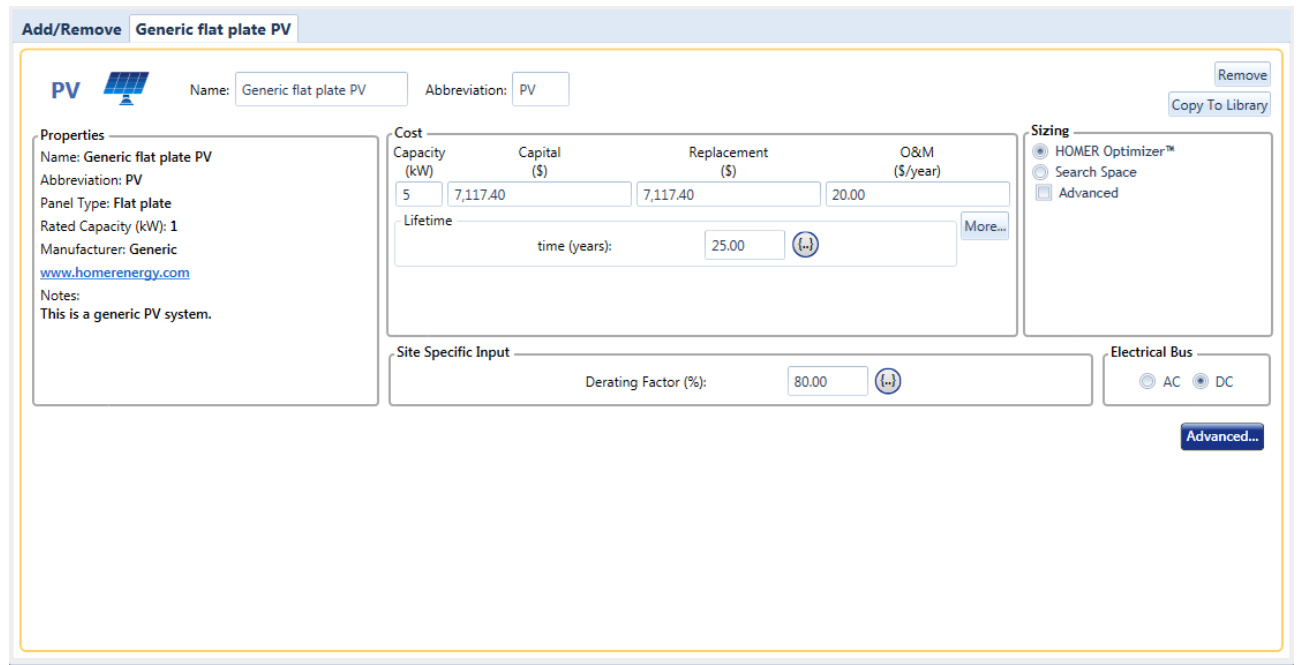

Gambar 9. Komponen PV

\section{Hasil dan Pembahasan}

Perhitungan oleh HOMER Pro dilakukan setelah semua langkah di atas selesai. Hasil simulasi ditunjukkan oleh Gambar 10, di mana baris pertama menunjukkan sistem yang paling direkomendasikan untuk diterapkan di Desa Koak. Tabel tersebut diurutkan berdasarkan keoptimalannya, sehingga yang paling bawah adalah sistem yang paling tidak direkomendasikan.

Pada baris pertama terlihat bahwa komponen yang digunakan adalah PV, turbin angin, baterai, dan converter. Genset tidak termasuk dalam sistem karena dianggap tidak optimal jika digabungkan dengan sistem tersebut. Sedangkan pada baris terakhir hanya menggunakan genset saja. Pada Gambar 10 juga terlihat spesifikasi komponen yang dibutuhkan, yaitu:

- Turbin angin $3 \mathrm{~kW}$ (1 buah), menghasilkan $0,081 \mathrm{~kW}$

- PV 5,11 kW, menghasilkan 0,971 kW atau 23,3 kWh/hari

- Baterai $1 \mathrm{kWh}, 12 \mathrm{~V}(29$ buah)

- Sistem converter $1,61 \mathrm{~kW}$

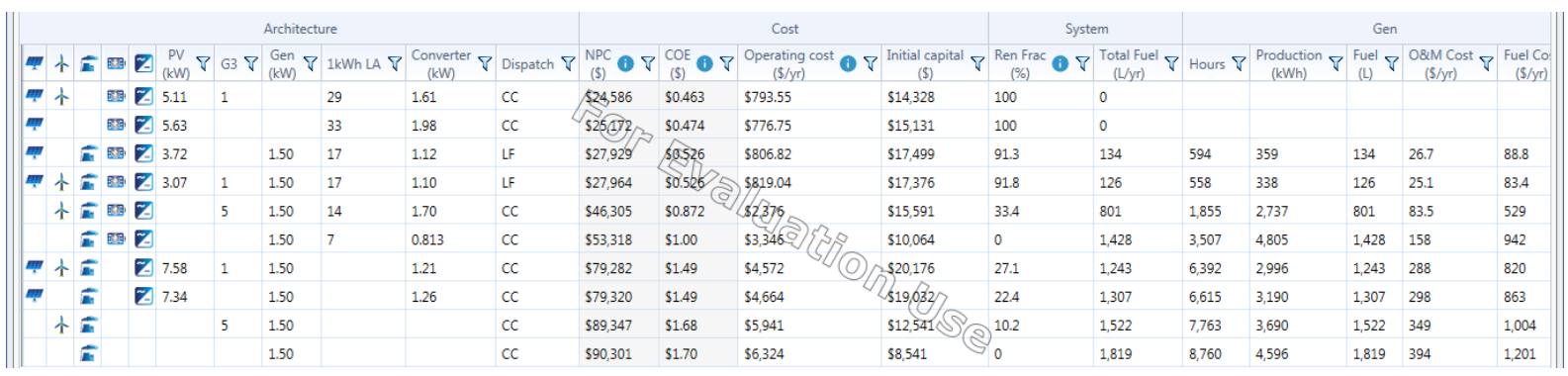

Gambar 10. Hasil simulasi dalam tabel

Dari hasil simulasi juga didapatkan data modal awal yaitu \$14328 dan NPC (Net Present Cost) sebesar $\$ 24586$. NPC pada sistem yang direkomendasikan merupakan yang terendah nilainya. Komponen yang membutuhkan biaya tertinggi adalah baterai, di mana NPC nya mencapai $\$ 15020,95$. Di sisi lain, komponen yang membutuhkan biaya terendah adalah converter, di mana NPC nya adalah $\$ 77,25$. Selanjutnya, pada baris paling bawah, yaitu sistem yang paling tidak direkomendasikan, modal awalnya hanya $\$ 8541$, namun NPC nya mencapai $\$ 90301$. Grafik biaya sistem yang direkomendasikan dapat dilihat pada Gambar 11. 


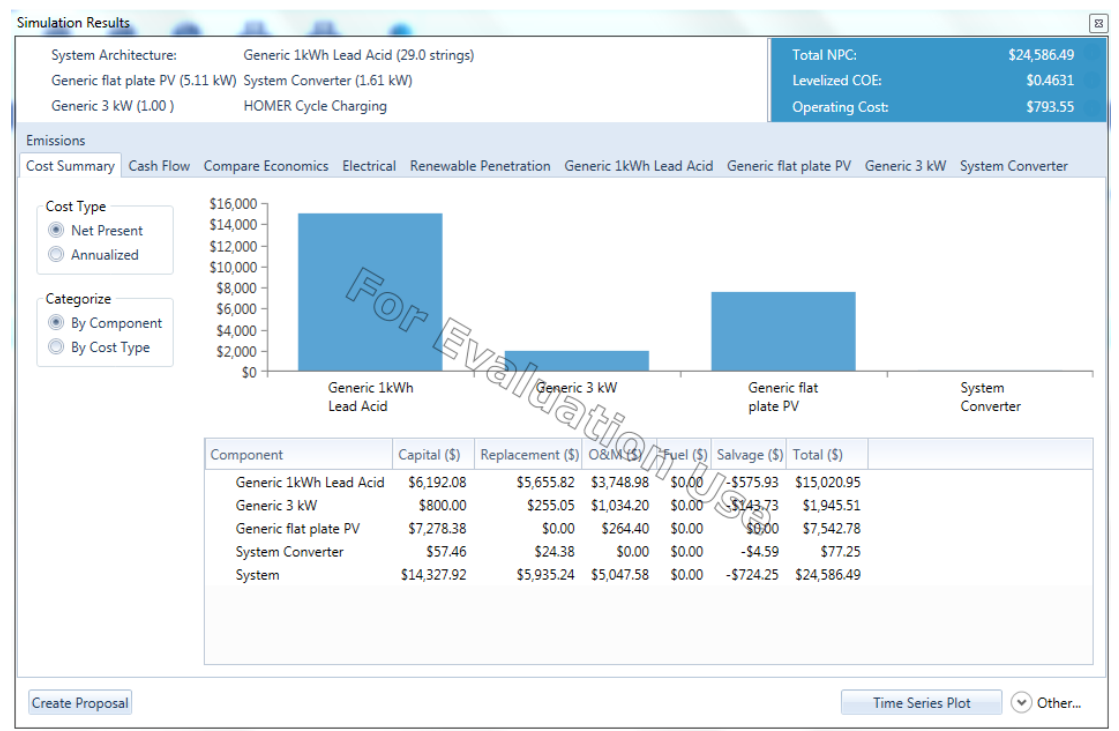

Gambar 11. Biaya yang dibutuhkan oleh sistem

Selain biaya, hasil simulasi juga menunjukkan daya per bulan yang diproduksi oleh sistem seperti terlihat pada Gambar 12. Dari Gambar 12 (a) terlihat bahwa terjadi fluktuasi tiap bulannya yang dipengaruhi oleh rata-rata radiasi matahari serta rata-rata kecepatan angin per bulan. Daya yang dihasilkan tersebut disumbang oleh energi surya sebesar $92,3 \%$ dan energi angin sebesar $7,7 \%$. Daya tertinggi yang bisa dihasilkan oleh sistem pada Gambar 12 (a) adalah mendekati 0,9 MWh. Kemudian Gambar 12 (b) merupakan sistem yang paling tidak direkomendasikan. Dari grafik terlihat bahwa daya yang dihasilkan lebih stabil, karena sumber energinya adalah solar. Akan tetapi, daya tertinggi yang bisa dihasilkan hanya sekitar 0,4 MWh.

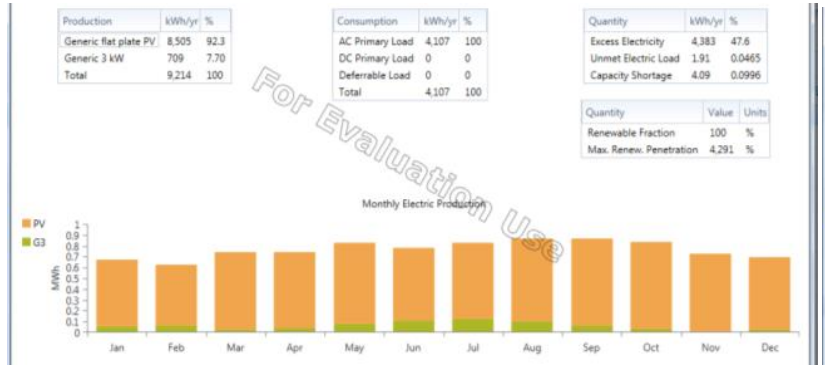

(a)

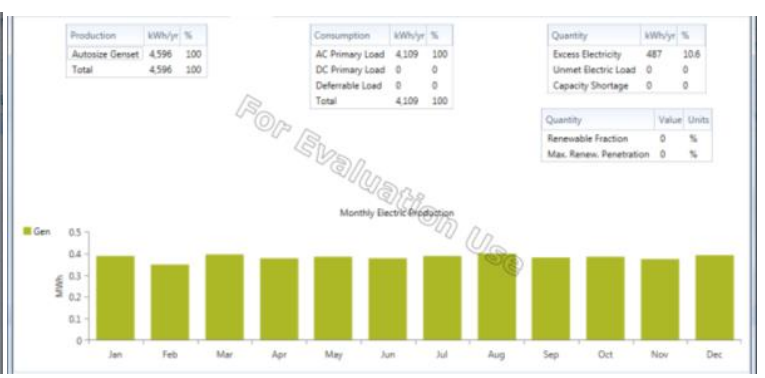

(b)

Gambar 12. Daya yang diproduksi oleh sistem (a) yang direkomendasikan dan (b) yang paling tidak direkomendasikan

Selanjutnya, hasil simulasi juga menunjukkan bahwa emisi yang dihasilkan oleh sistem pembangkit daya yang direkomendasikan adalah $0 \mathrm{~kg} / \mathrm{tahun}$ seperti terlihat pada Gambar 13 (a). Hasil tersebut menunjukkan bahwa sistem ini sangat ramah lingkungan. Hal ini tentu saja karena sumber daya yang digunakan adalah energi terbarukan. Kemudian, pada Gambar 13 (b) terlihat emisi yang dihasilkan oleh sistem yang paling tidak direkomendasikan. 


\begin{tabular}{|l|ll|l|l|l|l|}
\hline Quantity & Value & Units & & Quantity & Value & Units \\
\hline Carbon Dioxide & 0 & $\mathrm{~kg} / \mathrm{yr}$ & & Carbon Dioxide & 4,762 & $\mathrm{~kg} / \mathrm{yr}$ \\
Carbon Monoxide & 0 & $\mathrm{~kg} / \mathrm{yr}$ & Carbon Monoxide & 30.0 & $\mathrm{~kg} / \mathrm{yr}$ \\
Unburned Hydrocarbons & 0 & $\mathrm{~kg} / \mathrm{yr}$ & Unburned Hydrocarbons & 1.31 & $\mathrm{~kg} / \mathrm{yr}$ \\
Particulate Matter & 0 & $\mathrm{~kg} / \mathrm{yr}$ & Particulate Matter & 0.182 & $\mathrm{~kg} / \mathrm{yr}$ \\
Sulfur Dioxide & 0 & $\mathrm{~kg} / \mathrm{yr}$ & Sulfur Dioxide & 11.7 & $\mathrm{~kg} / \mathrm{yr}$ \\
Mitrogen Oxides & 0 & $\mathrm{~kg} / \mathrm{yr}$ & Nitrogen Oxides & 28.2 & $\mathrm{~kg} / \mathrm{yr}$
\end{tabular}

(a) (b)

Gambar 13. Emisi yang dihasilkan sistem (a) yang direkomendasikan dan (b) yang paling tidak direkomendasikan

\section{Kesimpulan}

Dari penelitian yang telah dilakukan, dapat ditarik beberapa kesimpulan sebagai berikut:

- Desa Koak memiliki potensi energi surya dan angin yang cukup baik sehingga bisa dimanfaatkan sebagai pembangkit daya.

- Hasil simulasi menunjukkan bahwa sistem hibrid paling optimal untuk Desa Koak adalah kombinasi PV dan turbin angin.

- Energi surya menyumbang produksi daya sebesar 92,3\% dari total daya yang dihasilkan, dan energi angin menyumbang sisanya, yaitu $7,7 \%$.

- Biaya awal yang dibutuhkan untuk membangun sistem ini adalah \$14328 dan NPC (Net Present Cost) sebesar \$24586.

- Sistem ramah lingkungan.

\section{Daftar Pustaka}

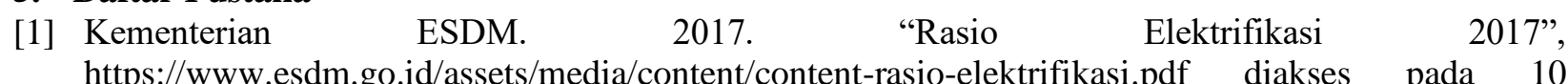
November 2020 pukul 11.41 WIB.

[2] BPS Kabupaten Manggarai. 2020. "Kecamatan Satar Mese dalam Angka 2020" https://manggaraikab.bps.go.id/publication/2020/09/28/52c043d61d2180791c7962ce/kecamatansatar-mese-dalam-angka-2020.html diakses pada 11 November 2020 pukul 20.35 WIB.

[3] Google Maps. 2020. "Peta Kecamatan Satar Mese, Kabupaten Manggarai". https://www.google.com/maps?q=satar+mese+manggarai\&rlz=1C1CHWL_enID803ID803\&um=1\& ie $=U T F-8 \& s a=X \& v e d=2 a h U K E w i Z 6 o X z w p X t A h V \_T j A B H b c c A t k Q \_A U o A X o E C A Y Q A w$ diakses pada 10 November pukul 14.15 WIB. 
